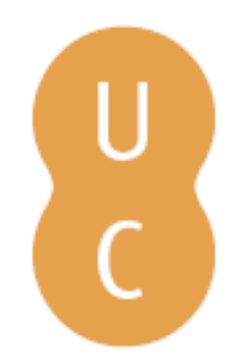



\section{Reitor da Universidade de Coimbra}

Autor(es): $\quad$ Silva, João Gabriel

Publicado por: Imprensa da Universidade de Coimbra

URL

persistente: URI:http://hdl.handle.net/10316.2/31186

DOI: $\quad$ DOI:http://dx.doi.org/10.14195/978-989-26-0437-4_1

Accessed : $\quad$ 26-Apr-2023 13:05:22

A navegação consulta e descarregamento dos títulos inseridos nas Bibliotecas Digitais UC Digitalis, UC Pombalina e UC Impactum, pressupõem a aceitação plena e sem reservas dos Termos e Condições de Uso destas Bibliotecas Digitais, disponíveis em https://digitalis.uc.pt/pt-pt/termos.

Conforme exposto nos referidos Termos e Condições de Uso, o descarregamento de títulos de acesso restrito requer uma licença válida de autorização devendo o utilizador aceder ao(s) documento(s) a partir de um endereço de IP da instituição detentora da supramencionada licença.

Ao utilizador é apenas permitido o descarregamento para uso pessoal, pelo que o emprego do(s) título(s) descarregado(s) para outro fim, designadamente comercial, carece de autorização do respetivo autor ou editor da obra.

Na medida em que todas as obras da UC Digitalis se encontram protegidas pelo Código do Direito de Autor e Direitos Conexos e demais legislação aplicável, toda a cópia, parcial ou total, deste documento, nos casos em que é legalmente admitida, deverá conter ou fazer-se acompanhar por este aviso.

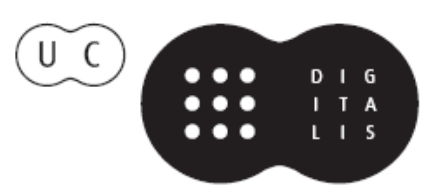




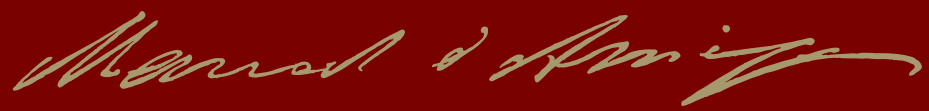

-

-

-

-

-

-

○

-

-

-

-

-

-

-

-

-

-

- 


\section{REITOR \\ DA UNIVERSIDADE \\ DE COIMBRA \\ João Gabriel Silva}


(Página deixada propositadamente em branco) 
Nas salas e corredores da Reitoria da Universidade de Coimbra (UC) pode assistir-se a uma homenagem permanente àqueles que serviram a instituição, ao mais alto nível, nos seus mais de sete séculos de história.

Cada um dos 77 retratos dos reitores da Universidade evoca a história de um período mas, sobretudo, a história de um homem. A duração dos mandatos, sempre visível nas pinturas, varia entre poucos meses e muitos anos: como em tantas outras situações, não é o tempo que conta mas antes o que cada um fez com ele.

Representado por António Carneiro em 1917, e atualmente em exposição num gabinete da Reitoria, encontramos, entre os seus pares, Manuel de Arriaga.

Na moldura, a data, 1910, evoca esse ano da instauração da República. Mas, em concreto, a referência temporal capta o escasso intervalo de tempo que durou o mandato daquele que foi o primeiro Reitor da República e que deixou de o ser para pouco depois se tornar no primeiro Presidente da República eleito em Portugal. 
António Carneiro, o pintor, ficou para a história da pintura portuguesa como "retratista de almas". O que fica, afinal, da alma de Arriaga na Reitoria da UC? O olhar determinado, o rosto erguido e o perfil voltado para o futuro.

Foi, de facto, curto o mandato de Manuel de Arriaga à frente dos destinos da Universidade. Mas a marca que deixou transcende a imagem no retrato.

No ano em que se encerram as comemorações do centenário da República, muitos sinais dessa passagem são lembrados pelo texto do Prof. Luís Reis Torgal. Não podemos deixar de assinalar a forma generosa como acedeu ao repto da Associação de Alunos - do Liceu da Horta, lançado pelo Prof. Melo Barreiros, seu presidente, de lembrar desta forma o primeiro Reitor da República. É com muito gosto e orgulho na sua história que a UC se associa a este gesto de memória.

Evocar Manuel de Arriaga naquela que foi, também a sua casa, é honrar a memória para continuar a construir o futuro, inspirados por quem, no seu tempo, teve a coragem de o fazer. 